Jurnal Personalia, Financial, Operasional,

Marketing dau Sistern Informasi

Performance. Volume 27 Nomor 1 Tahun 2020, 30-40

\title{
ANALISIS KELAYAKAN INVESTASI KEUANGAN HAJI DALAM PEMBIAYAAN INFRASTRUKTUR DAN TINGKAT IMBAL HASIL BADAN PENGELOLA KEUANGAN HAJI (BPKH)
}

\author{
Beny Witjaksono \\ Anggota Badan Pelaksana-Badan Pengelola Keuangan Haji \\ Pasca Sarjana Universitas Esa Unggul \\ *Email corresponding author: benywitjak@gmail.com \\ Diterima 23/09/2019 Direvisi 16/01/2020 Diterbitkan 31/01/2020
}

\begin{abstract}
Abstrak
Penelitian ini menganalisis portofolio investasi dana haji dalam pembiayaan infrastruktur dan tingkat pengembalian yang dikelola oleh Badan Manajemen Keuangan Haji (BPKH). Penelitian ini dilakukan melalui studi kasus dan studi literatur untuk memperoleh data sekunder. Data yang dikumpulkan dianalisis secara deskriptif kuantitatif dan kualitatif. Hasil penelitian menunjukkan bahwa kelayakan investasi dalam dana haji dalam pembiayaan infrastruktur layak berdasarkan UU 34/2014. Jenis pembiayaan infrastruktur dilakukan melalui pembelian sekuritas dalam bentuk perusahaan Sukuk dan MTN korporat. Berdasarkan UU 34/2014, investasi keuangan haji bertujuan untuk mendapatkan manfaat nilai optimal untuk meningkatkan layanan implementasi haji dengan memprioritaskan aspek keselamatan/Integritas dana calon peziarah.
\end{abstract}

Kata Kunci: Kelayakan, Investasi, Keuangan haji, Pembiayaan Infrastruktur, Imbal Hasil.

\begin{abstract}
This paper analyzes the investment portfolio of hajj funds in infrastructure financing and the level of returns managed by the Hajj Financial Management Board (BPKH). This research was conducted through case studies and literature studies to obtain secondary data. Data collected were analyzed quantitatively and qualitatively descriptive. The results showed that the feasibility of investment in hajj funds in infrastructure financing is feasible under Law $34 / 2014$. The type of infrastructure financing is done through the purchase of securities in the form of Sukuk corporations and corporate MTNs Under Law 34/2014, Hajj financial investments are aimed at obtaining optimal value benefits for improving the service of Hajj implementation by prioritizing aspects of the safety/integrity of the funds of prospective pilgrims.

Keywords: Feasibility, Investment, Hajj Finance, Infrastructure Financing, Yields.
\end{abstract}




\section{PENDAHULUAN}

Tumbuh rata-rata di atas 5 persen dalam kurun tahun 2016 - 2018, perekonomian Indonesia memiliki perkembangan yang positif yang mengindikasikan kesejahteraan penduduk meningkat. Data dari Badan Pusat Statistik (BPS) menyebutkan terdapat kenaikan per kapita Indonesia untuk Produk Domestik Bruto (PDB) menjadi US\$ 3.927 atau sekitar Rp56 juta per tahun di 2018. Angka tersebut naik dari tahun 2017 yang sebesar Rp51,9 juta dan 2016 yang sebesar Rp47,9 juta.

Kesejahteraan yang meningkat memungkinkan masyarakat turut berpartisipasi dalam kegiatan sosial, ekonomi serta keagamaan yang lebih luas, sebagai contoh ibadah haji. Ibadah haji merupakan ibadah yang mensyaratkan kemampuan baik fisik maupun finansial. Jumlah pendaftar ibadah haji setiap tahun dapat melebihi jumlah kuota haji. Kuota haji reguler sebanyak 204.000, sedangkan pendaftar dapat mencapai 600.000 dengan masa tunggu terlama dapat mencapai 39 tahun di wilayah Sulawesi Selatan (Kompas, 12 Februari 2019).

Setoran awal untuk pendaftaran haji dilakukan mulai tahun 2004 sesuai dengan langkah kebijakan yang ditetapkan pemerintah melalui Kementerian Agama. Kemudian tahun 2010, untuk mendaftar haji reguler setoran awal yang ditetapkan pemerintah adalah Rp25 juta per jemaah. Niat untuk menunaikan haji menjadi salah satu faktor pemacu yang menyebabkan tingginya umat Islam Indonesia untuk mendaftar ibadah haji sehingga daftar tunggu keberangkatan haji juga semakin panjang. Dana yang terakumulasi dari setoran awal tersebut setiap tahun juga akan mengalami peningkatan.

Kondisi tersebut mendorong adanya kebijakan pengelolaan keuangan haji dari rekening giro ke deposito, penyertaan saham pada PT Bank Muamalat Indonesia Tbk, serta pembelian Surat Berharga Syariah Negara (SBSN)/Sukuk (Kementerian Agama, 2015). Tercatat bahwa saldo dana setoran awal pada 31 Mei 2015 sebesar Rp73,9 triliun dengan komposisi penempatan pada deposito sebesar Rp37,2 triliun, sukuk sebesar Rp32,2 triliun dan giro Rp4,5 triliun. Sedangkan per tahun 2018 sesuai data dari laporan keuangan audit BPKH, keuangan haji yang dikelola adalah sebesar Rp113 triliun, terdiri atas penempatan pada Bank berupa Tabungan, Giro dan Deposito sebesar Rp65,4 triliun dan pada instrumen berupa Sukuk, reksadana, penyertaan saham, serta SBSN adalah sebesar Rp47,6 triliun.

Indonesia dihadapkan pada penyediaan infrastruktur guna menunjang pembangunan negara. RPJMN 2020-2024 menyebutkan kebutuhan investasi sebesar Rp36.595,6 - 37.447,6 triliun. Dari total kebutuhan tersebut, BUMN dan pemerintah akan menyumbang 7,6 - 7,9 persen dan 11,613,8 persen, sementara sisanya akan dipenuhi oleh masyarakat atau swasta. Berdasarkan hal tersebut, maka diperkirakan terdapat kebutuhan pembiayaan sebesar Rp29.321 triliun guna memenuhi financing gap yang ada. Karenanya, pembiayaan dari berbagai sumber untuk memenuhi kebutuhan pembiayaan infrastruktur tersebut dibutuhkan oleh pemerintah.

Tingkat kepuasan penyelenggaraan haji tahun 2018 menurut BPS (2018) adalah 85,23\% yang secara umum layanan pemerintah kepada jemaah haji telah cukup memuaskan. Namun demikian, tantangan ke depan yang akan dihadapi cukup berat mengingat setiap tahun biaya haji akan terus bertambah, sedangkan setoran awal hingga saat ini sejak tahun 2010 tetap Rp25jt. Untuk itu, optimalisasi nilai manfaat yang didapatkan dari pengelolaan keuangan haji diperlukan guna memberikan pelayanan yang lebih optimal kepada jemaah haji, sehingga diversifikasi pengelolaan keuangan haji diperlukan. Adapun nilai manfaat dari hasil pengelolaan dana keuangan haji digunakan untuk subsidi biaya haji bagi masyarakat Indonesia. Tidak hanya melalui surat berharga, giro dan deposito, namun berupa investasi langsung dan lainnya. Terdapat pendapat dari sebagian pihak yang mengusulkan pengeloaan keuangan haji salah satunya bisa dijadikan sumber pembiayaan bagi infrastruktur sehingga dimungkinkan untuk memperoleh nilai manfaat yang lebih optimal. Sedangkan disisi lain, terdapat pihak yang memberikan pendapat bahwa investasi melalui pembiayaan infrastruktur memiliki risiko yang tinggi. 


\section{PERFORMANCE}

Jurnal Personalia, Financial, Operasional,

Marketing dau Sistern Informasi

Performance. Volume 27 Nomor 1 Tahun 2020, 30-40

Biaya haji reguler riil pada tahun 2019 sebesar Rp69,7 juta/ jemaah, namun masyarakat hanya membayar Rp35,2 juta/ jemaah. Kekurangan dari pembiayaan tersebut disubsidi oleh BPKH dari nilai manfaat yang didapatkan melalui optimalisasi pengelolaan keuangan haji. Terdapat pandangan bahwa keuangan haji dapat dioptimalkan dengan masuk kepada sektor infrastruktur untuk memperoleh nilai manfaat yang lebih optimal. Pembiayaan infrastruktur yang bersumber dari pengelolaan keuangan haji memunculkan dilema dikalangan masyarakat. Pembiayaan infrastruktur dapat memberikan nilai manfaat yang cukup besar, dan setiap investasi memiliki risiko. Berdasarkan hal tersebut, investasi melalui infrastruktur dengan sumber pendanaan dari keuangan haji memerlukan kajian/ pertimbangan lebih lanjut dengan mempertimbangkan keuangan haji merupakan dana yang berasal dari setoran jemaah haji.

Oleh sebab itu, dilakukankah kajian terkait dengan kesesuaian kebijakan dalam investasi keuangan haji melalui proyek infrastruktur didasarkan dengan Undang-Undang Nomor 34 Tahun 2014 tentang Pengelolaan Keuangan Haji. Kesesuaian dengan undang-undang dapat memberikan keyakinan kepada masyarakat tentang keamanan keuangan haji yang dikelola.

\section{TINJAUAN PUSTAKA DAN PERUMUSAN HIPOTESIS}

Prasetyia (2011) menyatakan bahwa kesejahteraan material maupun non material merupakan tujuan utama dari sistem ekonomi nasional. Salah satu instrumen pemerintah untuk mewujudkan hal tersebut melalui kebijakan fiskal. Tema dan arah kebijakan fiskal tahun 2020, kebijakan APBN dituangkan dalam bentuk program prioritas pembangunan, salah satunya adalah akselerasi pembangunan infrastruktur untuk mendukung transformasi ekonomi (Republik Indonesia, 2020).

The World Bank mengkategorikan infrastruktur menjadi tiga golongan yaitu: Infrastruktur ekonomi, terkait dengan infrastruktur yang digunakan sebagai penunjang ekonomi bangsa. (contoh: infrastruktur sanitasi udara, subsidi gas, dan terkait utilitas publik), infrastruktur sosial, terkait dengan kondisi sosial masyarakat (contoh: kesehatan, Pendidikan, rekreasi, dan perumahan), infrastruktur terkait administrasi (contoh: kontrol administrasi dan hukum, serta koordinasi administrasi).

Infrastruktur sebagai barang publik dapat memberikan dampak positif terhadap ekonomi masyarakat karena dapat menyokong berbagai aspek sosial dan ekonomi. Bintoro (2012) menyebutkan bahwa selain APBN/ APBD, pembangunan infrastruktur dapat bersumber dari pinjaman kepada bank, privatisasi, CSR, dan penerbitan obligasi. Pengambilan keputusan untuk melakukan investasi pada suatu sektor usaha, termasuk proyek infrastruktur memerlukan kehatihatian dalam prosesnya termasuk metode evaluasi dari nilai suatu proyek. Evaluasi dari suatu proyek secara sistematis dapat dibagi menjadi tiga kategori yaitu metode berdasarkan return / tingkat pengembalian, metode berdasarkan risiko, dan metode berdasarkan return dan risiko. Metode berdasarkan return meliputi payback period, average accounting rate of return, Net Present Value (NPV) dan IRR. Payback period dan average accounting rate of return adalah tidak memperhatikan time value of money sedangkan NPV dan IRR memperhatikan time value of money ke dalam pengambilan keputusan menggunakan teknik counted cash flow techniques.

Metode berdasarkan risiko menggunakan pertimbangan risk rating system, dimana suatu investasi dievaluasi dan dinilai berdasarkan peringkat risiko. Pengambilan keputusan untuk melakukan investasi pada suatu sektor usaha didasarkan metode ini dengan melihat rating dari perusahaan/ lembaga terpercaya yang memiliki license untuk menyediakan suatu peringkat atas risiko kredit secara objektif, independent dan dapat dipertanggungjawabkan. Parameternya adalah investasi dapat dilakukan apabila perusahaan yang akan di investasikan tergolong dalam investment grades, sebagai contoh BBB atau di atas BBB menurut Standard \& Poor's rating atau Baa atau di atasnya dalam Moody's rating (Ye dan Tiong, 2000) sedangkan di Indonesia, terdapat PT Perusahaan Pemeringkat Efek Indonesia (PT Pefindo) yang bermitra dengan Standard \& Poor's 
Jurnal Personalia, Financial, Operasional,

Marketing dau Sistem Informasi

Performance. Volume 27 Nomor 1 Tahun 2020, 30-40

Rating Services (S\&P's). Metode Return dan Risk meliputi Utility theory, Cumulative distribution analysis, Decision Tress, dan Mean Return Variance. Lebih lanjut, Ye dan Tiong (2000) membagi kategori metode pengambilan keputusan sebagai pertimbangan melakukan investasi dalam bagan sebagai berikut:

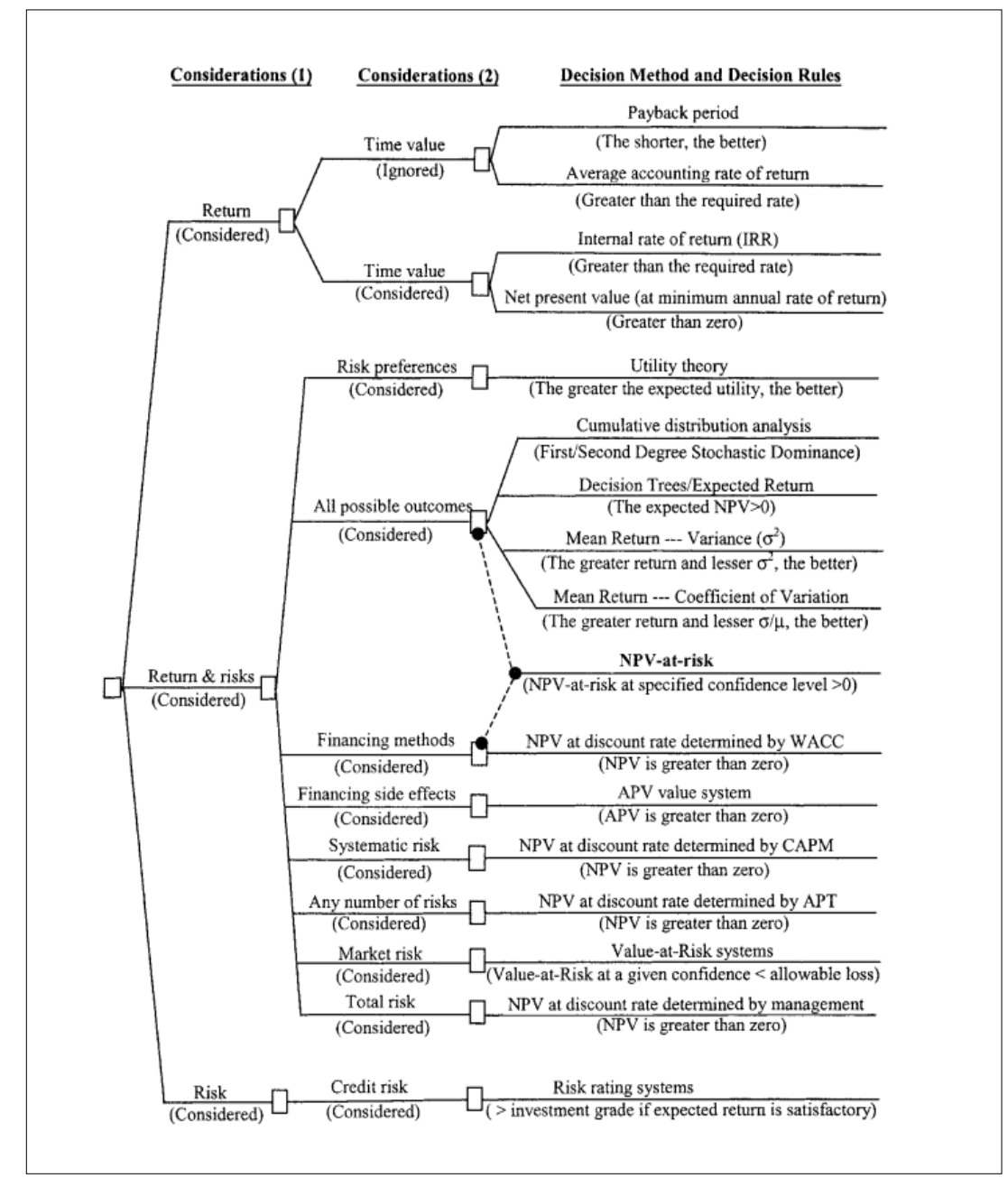

Gambar 1. Metode dan Aturan Pengambilan Keputusan untuk Capital Investment Decisions

Gurau (2012) menjelaskan bahwa evaluasi terhadap investasi dapat juga dilihat dari profitability index (PI) sebagai indikator dalam proses penilaian terhadap financial performance. $\mathrm{PI}$ merujuk pada rasio dari discounted benefits terhadap discounted costs atau dengan kata lain merupakan evaluasi dari profitabilitas terhadap investasi yang dibandingkan dengan profitabilitas pada investasi sejenis lainnya dan mengekspors. Selain itu, PI dapat dilihat dari benefit-cost ratio, cost-benefit ratio, maupun even capital rationing.

Aspek Investasi dalam Pengelolaan Keuangan Haji

Sesuai dengan UU No. 34/ 2014, investasi keuangan haji dilakukan sesuai dengan prinsip syariah dengan mempertimbangkan aspek keamanan, kehati-hatian, nilai manfaat, dan likuiditas. Berikut ini merupakan pasal-pasal dalam undang-undang no. 34 tahun 2014 tentang pengelolaan keuangan haji : 
Tabel 1. Pasal Terkait Investasi dalam UU No.34 Tahun 2014

\begin{tabular}{ccl}
\hline No. & Pasal dalam UU No. 34 Tahun 2014 & \multicolumn{1}{c}{ Keterangan } \\
\hline 1 & Pasal 20 sampai 33 & Wewenang BPKH dalam menempatkan dan \\
& & menginvestasikan keuangan haji serta melakukan \\
& kerjasama dengan lembaga lainnya. \\
\hline 2 & Pasal 40 ayat 1 & Penempatan dan atau investasi keuangan haji \\
& dilakukan dalam bentuk produk perbankan, surat \\
& berharga, emas, investasi langsung dan investasi \\
& lainnya. & \\
\hline 3 & Pasal 46 & Mengatur tata cara pengelolaan keuangan haji. \\
& & Pasal tersebut mewajibkan pengelolaan \\
& keuangan haji dilakukan di bank umum syariah \\
& dan atau unit usaha syariah. Di samping itu, \\
& pengelolaan keuangan haji dapat diinvestasikan \\
& sesuai dengan prinsip syariah dengan \\
& mempertimbangkan aspek keamanan, kehati- \\
& hatian, nilai manfaat dan likuiditas. \\
\hline
\end{tabular}

Sumber: UU No.34 tahun 2014 tentang Pengelolaan Keuangan Haji

Sebagai tambahan dalam peraturan lainnya, disebutkan sebagai berikut:

Tabel 2. Peraturan Lainnya Terkait Penyelenggaraan Ibadah Haji

\begin{tabular}{|c|c|c|}
\hline No. & Jenis Peraturan & Keterangan \\
\hline 1 & $\begin{array}{l}\text { UU No. } 10 \text { tahun } 1998 \text { tentang } \\
\text { Perbankan }\end{array}$ & $\begin{array}{l}\text { Kriteria surat berharga mencakup suatu } \\
\text { kepentingan (seperti saham) atau suatu } \\
\text { kewajiban dari penerbit (seperti obligasi) dalam } \\
\text { bentuk yang lazim diperdagangkan dalam pasar } \\
\text { modal dan pasar uang. }\end{array}$ \\
\hline 2 & $\begin{array}{l}\text { Pasal } 26 \text { PP No. } 75 \text { tahun } 2018 \\
\text { tentang Pelaksanaan UU No. } 34 \\
\text { tahun } 2014 \text { tentang pengelolaan } \\
\text { keuangan haji }\end{array}$ & $\begin{array}{l}\text { Pengeluaran untuk investasi keuangan haji dapat } \\
\text { dilakukan dalam bentuk surat berharga, emas, } \\
\text { investasi langsung dan investasi lainnya. }\end{array}$ \\
\hline 3 & $\begin{array}{l}\text { Pasal } 18 \text { Perpres No. } 110 \text { tahun } 2017 \\
\text { tentang Badan Pengelola Keuangan } \\
\text { Haji }\end{array}$ & $\begin{array}{l}\text { Menempatkan dan menginvestasikan keuangan } \\
\text { haji sesuai dengan prinsip syariah, kehati-hatian, } \\
\text { keamanan, dan nilai manfaat. }\end{array}$ \\
\hline 4 & $\begin{array}{l}\text { PP No. } 49 \text { tahun } 2011 \text { tentang } \\
\text { perubahan peraturan pemerintah } \\
\text { No. } 1 \text { tahun } 2008 \text { tentang investasi } \\
\text { pemerintah }\end{array}$ & $\begin{array}{l}\text { Investasi langsung sebagai penyertaan modal dan } \\
\text { atau pemberian pinjaman oleh badan investasi } \\
\text { pemerintah untuk membiayai kegiatan usaha. } \\
\text { Investasi lainnya mencakup kegiatan investasi } \\
\text { yang luas. }\end{array}$ \\
\hline
\end{tabular}

Sumber: UU No. 10 tahun 1998, PP No.5 Tahun 2008, Perpres No. 110 Tahun 2017, PP No. 49 Tahun 2011

Ascarya dan Humanita (2005) menyebutkan bahwa deposito syariah merupakan salah satu produk yang dapat digunakan sebagai bentuk investasi. Sakinah (2014) menjelaskan bahwa akad mudrabah mutlaqoh dan mudarabah al-muqayyadah dapat digunakan dalam pengembangan produk perbankan syariah. Sinurat (2010) menyatakan bahwa pembelian obligasi, penyertaan modal, atau pinjaman secara langsung kepada perusahaan/ institusi/ proyek termasuk kategori 
Performance. Volume 27 Nomor 1 Tahun 2020, 30-40

investasi langsung. Setiarsih (2014) disisi lain menjelaskan bahwa investasi pada aset riil seperti tanah bangunan, mesin, dan penyertaan reksadana disebut sebagai investasi lainnya. Kriteria investasi sesuai pasal 46 dalam UU No. 34 tahun 2014 harus memenuhi aspek keamanan, nilai manfaat, likuiditas, dan prinsip kehati-hatian.

\section{METODE PENELITIAN}

Pendekatan kualitatif dengan metode deskriptif merupakan metode yang dipilih. Gambaran maupun penjelasan terhadap suatu permasalahan dapat digambarkan melalui metode deskriptif, sedangkan kajian pustaka digunakan sebagai sumber pengumpulan data.

\section{HASIL DAN PEMBAHASAN}

\section{Investasi Keuangan Haji Dan Pembiayaan Infrastruktur}

Terdapat peningkatan kelolaan keuangan haji sejak 2014-2018 yang berasal dari setoran awal biaya haji (Tabel 3) dan dimungkinkan untuk terus dapat meningkat pada tahun berikutnya.

Tabel 3. Nilai Keuangan Haji Tahun 2014-2018 (Triliun Rupiah)

\begin{tabular}{lccccc}
\hline \multicolumn{1}{c}{ Tahun } & 2014 & 2015 & 2016 & 2017 & 2018 \\
\hline $\begin{array}{l}\text { Akumulasi Keuangan haji } \\
\text { (Triliun Rupiah) }\end{array}$ & 73.8 & 81.5 & 90.6 & 102.51 & 112.35 \\
\hline Peningkatan (persen) & $14.42 \%$ & $10.43 \%$ & $11.17 \%$ & $13.15 \%$ & $9.60 \%$ \\
\hline
\end{tabular}

Sumber: Kemenag, BPKH, diolah

Pasal 7 ayat (1) UU No. 34 tahun 2014 menyebutkan bahwa setoran Biaya Penyelenggaraan Ibadah Haji (BPIH) dan/atau BPIH Khusus merupakan dana titipan jamaah haji untuk Penyelenggaraan Ibadah Haji. Bentuk pengelolaan keuangan haji yang diterapkan oleh Tabung Haji di Malaysia secara ringkas dapat di lihat pada tabel berikut ini:

Tabel 4. Pengelolaan Keuangan Haji pada Tabung Haji Malaysia

\begin{tabular}{cll}
\hline No. & Pengelolaan Keuangan Haji & \multicolumn{1}{c}{ Keterangan } \\
\hline 1 & Tahun 1969 & Tabung haji dibentuk \\
\hline 2 & Bentuk investasi & Penyertaan modal di perusahaan publik dan non \\
& & publik, proyek joint venture dan proyek swasta, \\
& & investasi pada sektor perkebunan, industri, \\
& komersial, rel estate, pembelian di bursa saham, \\
& pengelolaan properti dan usaha yang \\
& & menguntungkan lainnya. \\
\hline 3 & Prinsip usaha yang digunakan & Berprinsip syariah. \\
\hline 4 & Bentuk imbal hasil & Dividen, bonus, laba, imbal hasil atas jasa sewa \\
& & gedung.
\end{tabular}

Sumber: Mannan, 1996 
Tabel 5. Perbandingan Pengelolaan Keuangan haji Indonesia dan Malaysia

\begin{tabular}{|c|c|c|}
\hline Keterangan & Indonesia & Malaysia (Tabung Haji) \\
\hline Pengelola & Pemerintah (kementerian agama) & Badan Usaha Milik Negara \\
\hline Tujuan setoran & $\begin{array}{l}\text { Sebagai biaya perjalanan ibadah } \\
\text { haji, meliputi layanan akomodasi, } \\
\text { konsumsi, kesehatan, transportasi, } \\
\text { perlindungan, dan layanan terkait } \\
\text { ibadah haji lainnya yang termasuk } \\
\text { hak dari penyetor. }\end{array}$ & $\begin{array}{l}\text { Daftar haji dan atau komersial } \\
\text { (keuntungan investasi) }\end{array}$ \\
\hline $\begin{array}{l}\text { Jaminan } \\
\text { pemerintah }\end{array}$ & $\begin{array}{l}\text { Dana setoran jamaah haji dijamin } \\
\text { oleh LPS sepanjang memenuhi } \\
\text { persyaratan yang ditetapkan. }\end{array}$ & $\begin{array}{l}\text { Seluruh deposan mendapatkan } \\
\text { jaminan }\end{array}$ \\
\hline Status dana & Dana titipan (wadi'ah) & $\begin{array}{l}\text { Tabungan dan } \\
\text { (pengembangan) }\end{array}$ \\
\hline Pengelolaan dana & $\begin{array}{l}\text { Dikelola oleh BPKH dengan } \\
\text { memperhatikan aspek keamanan, } \\
\text { kehati-hatian, nilai manfaat dan } \\
\text { likuiditas. }\end{array}$ & $\begin{array}{l}\text { Diversifikasi berbagai sektor/bidang } \\
\text { berorientasi profit }\end{array}$ \\
\hline $\begin{array}{l}\text { Pengembalian } \\
\text { penarikan dana }\end{array}$ & $\begin{array}{l}\text { Apabila jamaah haji tidak } \\
\text { memungkinkan berangkat haji. }\end{array}$ & $\begin{array}{l}\text { Meningkatkan penarikan dana oleh } \\
\text { deposan secara fleksibel }\end{array}$ \\
\hline
\end{tabular}

Sumber: UU No. 8 tahun 2019 dan Mannan (1996)

Wadiah atau disebut juga dana titipan dalam hukum Islam, dapat dikelola sesuai dengan akadnya. Terkait dengan pasal 7 ayat 1 dan pasal 46 UU No. 34 tahun 2014, bahwa setoran awal jemaah haji adalah sebagai titipan yang dimungkinkan untuk dikelola untuk menghasilkan nilai manfaat, mirip dengan prinsip wadiah yadh dhamanah. Prinsip ini memiliki pengertian bahwa pihak yang diberikan titipan memiliki tanggung jawab atas kehilangan maupun kerusakan yang timbul, dengan konsekuensi bahwa pihak penyimpan dapat memanfaatkan/ mendayagunakan titipan tersebut untuk aktivitas usaha sepanjang barang titipan tersebut dapat dikembalikan kembali secara utuh saat penyimpan mengambil kembali. Penyimpan bertindak sebagai penjamin barang/ aset yang dititipkan (Ascarya, 2006). Pemanfaatan aset titipan cenderung dilakukan dengan cara konservatif dan instrumen yang likuid (Acarya, 2006).

Pengelolaan keuangan haji dilakukan dengan memperhatikan jangka waktu investasi yang disesuaikan dengan kebutuhan pembiayaan operasional haji. Dilakukan investasi baik jangka pendek untuk menjaga likuiditas dan jangka panjang untuk optimalisasi nilai manfaat. Hal ini memberikan peluang penggunaan dana keuangan haji untuk investasi jangka panjang, termasuk di dalamnya infrastruktur.

Novianti (2011) menyatakan bahwa pembiayaan infrastruktur memerlukan dana yang cukup besar, dan payback period yang cukup panjang, serta dipengaruhi oleh faktor makro ekonomi suatu negara. Oleh karenanya, investasi dalam infrastrukur perlu diperhatikan aspek risiko yang mungkin timbul secara lebih seksama oleh calon investor, antara lain risiko operasional, risiko hukum, risiko kredit, risiko kepatuhan dan risiko reputasi. Pasal 48 ayat (1) dalam UU No. 34 tahun 2014 memungkinkan investasi keuangan haji pada investasi langsung maupun lainnya, termasuk pada infrastruktur sehingga kebutuhan pemerintah atas pembiayaan infrastrukutur nasional dapat dipenuhi melalui salah satu sumber yaitu keuangan haji.

Berdasarkan ketentuan Pasal 48 ayat (1) dalam UU No. 34 tahun 2014, kebijakan investasi keuangan haji dalam bentuk infrastruktur harus memenuhi aspek keamanan, kehati-hatian, nilai 


\section{PERFORMANCE}

Jurnal Personalia, Financial, Operasional,

Marketing dau Sistem Informasi

Performance. Volume 27 Nomor 1 Tahun 2020, 30-40

manfaat dan likuiditas. Alternatif investasi melalui proyek infrastruktur antara lain: Surat berharga Syariah Negara (SBSN)/ Sukuk dengan underlying proyek infrastruktur pemerintah yang dijamin oleh pemerintah Indonesia, deposito mudharabah al muqayyadah di perbankan dengan tujuan untuk investasi pada infrastruktur, surat berharga syariah atau sukuk yang diterbitkan pemerintah maupun korporasi dengan underlying proyek infrastruktur, pembiayaan secara langsung kepada perusahaan atau proyek infrastruktur, reksadana syariah dengan tujuan pembiayaan proyek infrastruktur.

\section{Investasi Infrastruktur dan Peningkatan Penyelenggaraan Ibadah Haji}

Inderst (2006) menyatakan bahwa saham yang dibeli dari suatu perusahaan dengan dasar berupa proyek infrastruktur baik pada pasar perdana maupun pasar sekunder, langsung maupun tidak langsung, pada perusahaan terdaftar di Bursa Efek maupun non terdaftar merupakan salah satu alternatif dalam investasi infrastruktur. Berdasarkan Peraturan Pemerintah No. 5 tahun 2018 proporsi investasi dan penempatan dana, yang dapat dilakukan oleh BPKH adalah sebagai berikut:

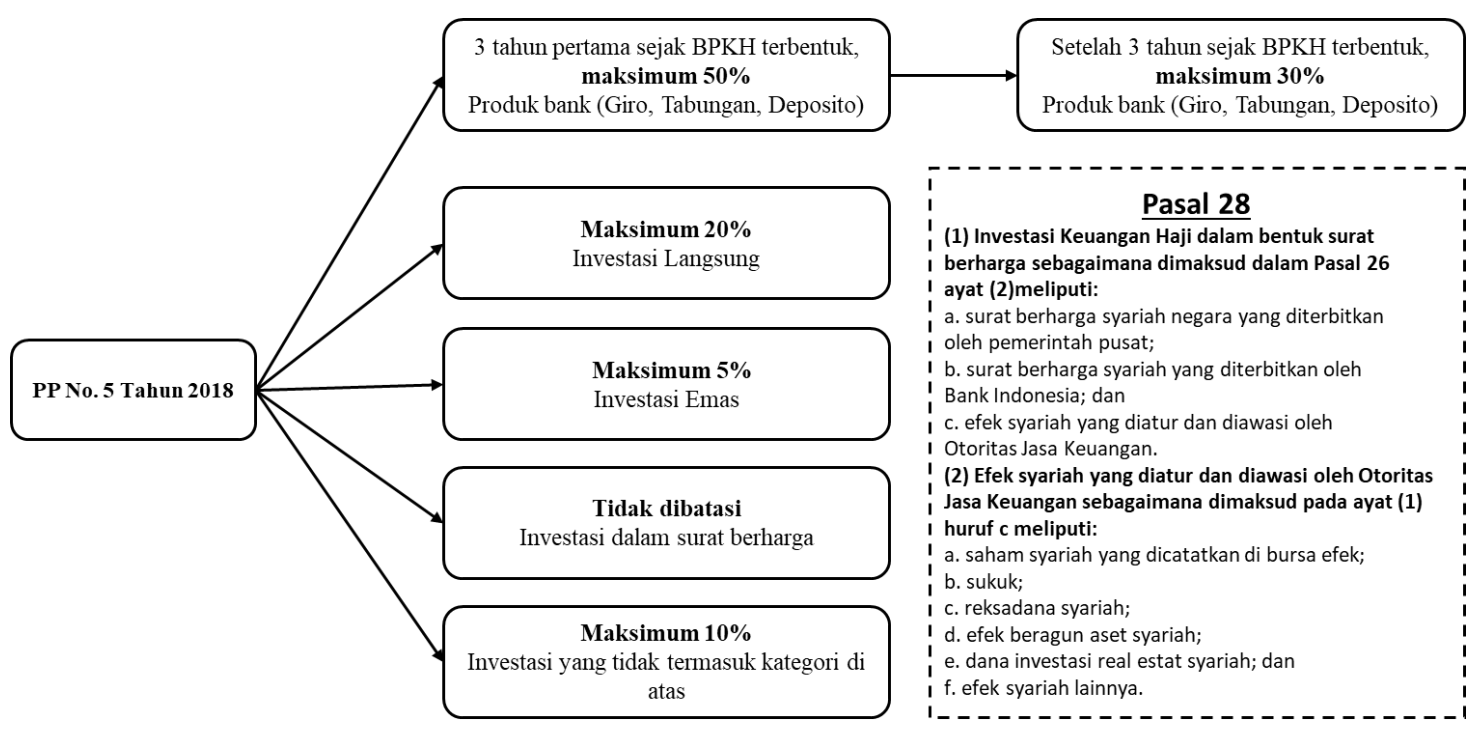

Gambar 2. Peraturan Pemerintah No. 5 tahun 2018 proporsi investasi dan penempatan dana yang dapat dilakukan oleh BPKH

Sebagai benchmark terhadap lembaga yang telah berdiri sebelumnya terkait dengan pengelolaan keuangan haji, salah satunya adalah Tabung Haji Malaysia. Tabung Haji memberikan imbal hasil yang rasional kepada deposan serta memiliki paket layanan haji yang dinilai menjadi salah satu yang terbaik di dunia (Mannan, 1996). UU No. 8 tahun 2019 tentang Penyelenggaraan Ibadah Haji dan Umrah Pasal 3, bahwa tujuan dari penyelenggaraan ibadah haji dan umrah adalah memberikan pembinaan, pelayanan, dan perlindungan bagi jemaah haji dan jemaah umrah sehingga dapat menunaikan ibadahnya sesuai dengan ketentuan syariat.

Kementrian Agama (2015) menyebutkan bahwa pemondokan, transportasi, akomodasi dan katering merupakan pelayanan dari pemerintah RI yang telah berjalan bagi warga negara Indonesia di Arab Saudi . Sedangkan di dalam negeri telah dijalankan bimibingan manasik haji, dokumen terkait ibadah haji, asrama haji di embarkasi, dan pesawat ke Arab Saudi. Selain itu semua, pemerintah berupaya melakukan peningkatan layanan penyelenggaraan ibadah haji dan optimalisasi nilai manfaat.

Revitalisasi asrama haji merupakan salah satu contoh infrastruktur haji dan dapat dibiayai dari APBN melalui SBSN maupun sukuk (Zainal, 2016). Pengelolaan keuangan haji dapat diinvestasikan 
Performance. Volume 27 Nomor 1 Tahun 2020, 30-40

pada sektor-sektor strategis pendukung pelayanan haji seperti pembelian pesawat, rumah sakti haji, asrama haji, catering haji, pendidikan terkait haji, pemondokan/hotel (As, 2014). Selain hal tersebut, investasi keuangan haji untuk pembiayaan insfrastruktur yang bertujuan untuk meningkatkan kualitas penyelanggaraan ibadah haji dapat menjadi bahan pertimbangan guna menghasilkan nilai manfaat yang lebih optimal dalam rangka memberikan maslahat bagi umat.

\section{KESIMPULAN}

Kesimpulan yang dapat diambil dari uraian di atas adalah keuangan haji dapat diinvestasikan dalam proyek pembiayaan infrastruktur dikarenakan sifat dari keuangan haji sebagai dana titipan, atau menyerupai prinsip wadiah yadh dhamanah. Adapun dari prinsip tersebut, dilihat dari perspektif keuangan syariah, memungkinkan bagi BPKH untuk optimalisasi nilai manfaat keuangan haji dengan mengutamakan keamanan/ kebutuhan dana jemaah haji. Maka investasi dalam bentuk pembiayaan infrastruktur dimungkinkan namun terbatas pada jenis investasi yang aman, syariah, dan dilakukan pada sektor yang telah memberikan nilai manfaat (brown field). Pembiayaan infrastruktur yang dapat menjadi sarana peningkatan kualitas penyelenggaran ibadah haji dapat difokuskan kepada sarana penerbangan, catering, akomodasi, transportasi darat baik dalam dan luar negeri dengan tetap memperhatikan aspek keamanan keuangan haji. Saran untuk penelitian selanjutnya adalah menggunakan metode penelitian lain yang mungkin dapat lebih menganalisis investasi keuangan haji.

\section{DAFTAR PUSTAKA}

Abidin, M. Zainul. (2016). Analisis investasi keuangan haji dalam pembiayaan infrastruktur dan peningkatan kualitas penyelenggaraan ibadah haji, Kementerian Agama RI. Jurnal Multikultural \& Multireligius 15/2, 152-163.

As. (2014, April). Menggagas Investasi Keuangan Haji. Majalah Realitas Haji Edisi I.

Ascarya dan Diana Humanita. (2005). Bank Syariah: Gambaran Umum, Seri Kebanksentralan No. 14, Jakarta: Pusat Pendidikan dan Studi Kebanksentralan Bank Indonesia.

Badan Pusat Statistik. (2018). Indeks Kepuasan Jemaah Haji Indonesia Tahun 1439H/2018M (No.95/11/Th.XXI). Jakarta: Penulis. Diakses dari https://www.bps.go.id/pressrelease/...2018m.html.

Bintoro, Ristu. (2012). Analisis Investasi Dana Asuransi Sebagai Alternatif Pembiayaan Infrastruktur Melalui Kerjasama Pemerintah Dengan Swasta (Tesis). Tersedia dari Fakultas Teknik, Universitas Indonesia.

Dewi, Retia Kartika (2019, 15 Februari). Kemenag Rilis Lamanya Antrean Haji Indonesia Sulsel Mencapai 39 Tahun. Kompas. Diakses dari https://nasional.kompas.com/read/2019/02/12/14250341/kemenag-rilis-lamanya-antreanhaji-indonesia-sulsel-mencapai-39-tahun.

Gurau, Marian Adrei. (2012). The use of profitability index in economic evaluation of industrial investment projects. Proceedings in Manufacturing Systems, 7/, 55-58. 
Inderst, George. (2006). Pension Funds Investment in Infrastructure, OECD Working Paper on Finance Insurance and Private Pensions, No.32, 1-45. Diakses dari https://doi.org/10.1787/19936397.

Kasri, Rahmatina Awaliah dkk (2018), Strategic Assets Allocation untuk optimalisasi untuk optimalisasi pengelolaan investasi keuangan haji di Indonesia, call for paper, Divisi Perencanaan dan Pengembangan Badan Pengelola Keuangan Haji, 2018.

Kementerian Agama (2015). Keputusan Menteri Agama tentang Rencana Strategis Kementerian Agama Tahun 2015-2019 (Nomor 39 Tahun 2015). Jakarta: Penulis. Diakses dari itjen.kemenag.go.id/...pdf.

Mannan, Mohammad Abdul. (1996). Islamic Socioeconomic Institutions and Mobilization of Resources With Special Reference To Hajj Management Of Malaysia, Research Paper No. 40. Jeddah: Islamic Research and Training Institute-Islamic Development Bank. Diakses dari http://ierc.sbu.ac.ir/...pdf.

Novianti, Trisita. (2011). Pemodelan Risiko Pendapatan Proyek Infrastruktur Jalan Tol dengan Pendekatan Fault Tree Analysis. Jurnal Teknik dan Manajemen Industri, 6/2, 138-149.

Pamungkas, Bagus Teguh. (2009). Pengaruh Infrastruktur Ekonomi, Sosial, dan Administrasi/ Institusi Terhadap Pertumbuhan Provinsi-Provinsi di Indonesia (Skripsi). Tersedia di Fakultas Ekonomi Universitas Indonesia.

Peraturan Pemerintah (2018). Peraturan Pemerintah tentang Pelaksanaan UU No. 34 tahun 2014 tentang Pengelolaan Keuangan Haji (No. 5 tahun 2018). Jakarta: Penulis. Diakses dari https://sipuu.setkab.go.id/...pdf.

Peraturan Pemerintah (2011). Peraturan Pemerintah tentang Perubahan Peraturan Pemerintah No. 1 tahun 2008 Tentang Investasi Pemerintah (No. 49 tahun 2011). Jakarta: Penulis. Diakses dari ditjenpp.kemenkumham.go.id/arsip/..pdf.

Peraturan Presiden (2017). Peraturan Presiden tentang Badan Pengelola Keuangan Haji (No. 110 tahun 2017). Jakarta: Penulis. Diakses dari https://peraturan.bpk.go.id/...2017.

Prasetyia, Ferry. (Oktober 2011). Rekonstruksi Sistem Fiskal Nasional Dalam Bingkai Konstitusi. Journal of Indonesian Applied Economics, 5/2, 141-156.

Kementrian Keuangan Republik Indonesia. (2020). Buku II Nota Keuangan Beserta APBN Tahun Anggaran 2020. Jakarta: Kementrian Keuangan Republik Indonesia.

Sakinah. (2014). Investasi Dalam Islam, Jurnal Iqtishadia, 1/2, 248-262.

Setiarsih, Annya Tri Andina. (2014). Analisis Perbandingan Kinerja Reksadana Campuran dan Reksadana Saham Dengan Menggunakan Metode Indeks Sharpe (Skripsi). Tersedia dari Fakultas Pendidikan Ekonomi dan Bisnis Universitas Pendidikan Indonesia.

Sinurat, Johannes A.P. (2010). Tinjauan Yuridis Terhadap Investasi Asing yang Hendak Melakukan Pembelian Saham Mayoritas Melalui Investasi Portofolio Dalam Pasar Modal (Ditinjau Dari 
Jumal Personalia, Financial, Operasional,

Marketing dam Sistern Informas

Performance. Volume 27 Nomor 1 Tahun 2020, 30-40

UU Nomor 8 Tahun 1995 Tentang Pasar Modal dan UU Nomor 25 Tahun 2007 Tentang Penanaman Modal) (Tesis). Tersedia dari Fakultas Hukum Universitas Indonesia.

The World Bank. (1994). Infrastructure for Development. World Bank Development Report. New York : Oxford University.

Undang-undang Nomor 10 tahun 1998 tentang Perbankan

Undang-undang Nomor 17 Tahun 2003 tentang Keuangan Negara.

Undang-undang Nomor 13 Tahun 2008 tentang Penyelenggaraan Ibadah Haji.

Undang-undang Nomor 34 Tahun 2014 tentang Pengelolaan Keuangan Haji.

Ye, Sudong dan Tiong, Robert L. (2000). NPV-At-Risk Method In Infrastructure Project Investment Evaluation. Journal of Construction Engineering and Management, 126/3, 227-233. Diakses dari https://doi.org/10.1061/(ASCE)0733-9364(2000)126:3(227). 